\title{
В.С. ПАВЛЕНКО-БАРИШЕВА
}

Інститут ботаніки імені М.Г. Холодного НАН України

вул. Терещенківська, 2, м. Київ, 01601, Україна

Ipilosella@mail.ru

\section{УЛЬТРАСТРУКТУРА ПОВЕРХНІ ПЛОДІВ ВИДІВ РОДУ НIЕRACIUМ ФЛОРИ КРИМУ}

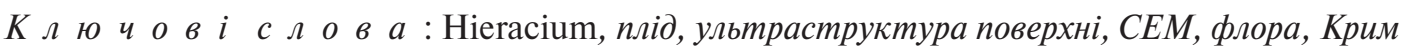

Сьогодні в систематиці увага дедалі частіше сконцентровується на карпологічних ознаках. Дослідження, проведені на багатьох об’єктах, підтверджують думку щодо можливості використання цих ознак як додаткових діагностичних для визначення секцій та видів (Sulaiman, 1995; Johnson et al., 2004; Ольшанський, 2009; Перегрим, Вакуленко, 2009). Вивчаючи плоди родини Asteraceae Bercht. et J. Presl., дослідники (Schneider, Boldrini, 2011; Shekhar, Pandey, Anderberg, 2011; Bednorz, Podsiedlik, 2013) враховують такі основні ознаки: характер ультраструктури поверхні плоду, зовнішня форма носика сім'янки, ребер, форма та розміри клітин екзокарпію, наявність виростів та інших структур. Дослідження ультраструктури поверхні сім'янок видів роду Hieracium L. проводилося в межах загального вивчення плодів триби Hieraciinae Dum. (Сенников, Илларионова, 2001). У результаті анатомічних та морфологічних досліджень виявлено значну різноманітність форми й анатомічної структури плодів. Чільну увагу приділяли кількості та характеристикам ребер. Результати дослідження О.М. Сеннікова та І.Д. Ілларіонової дали змогу підтвердити відмінності в морфології й анатомії плодів на секційному рівні. Досліджуючи плоди триби Hieraciinae, брали тільки по одному представникові з кожної секції. Отже, існує нагальна потреба у вивченні секцій у повному обсязі.

Рід Hieracium у флорі Криму представлений 10 видами (Черепанов, 1973; Шляков, 1989; Ена, 2012; Euro+Med Plant Base) із п’яти секцій: Foliosa (Fr.) Zahn, Accipitrina Koch, Umbellata (Fr.) Williams, Tridentata (Fr.) G. Schneid. та Hieracium. У літературі існують мікроморфологічні дані стосовно двох видів нечуйвітрів (H. umbellatum L., H. virosum Pall.), що зростають на території Криму. Нашою метою було вивчення ультраструктури поверхні плодів видів роду Hieracium флори Криму, з'ясування можливості використання ознак ультраструктури поверхні плоду для систематики роду.

( ) В.С. ПАВЛЕНКО-БАРИШЕВА, 2014

\section{Матеріали та методи дослідження}

Вивчено 10 видів нечуйвітрів флори Криму. Для з'ясування особливостей поверхні сім'янок видів роду Hieracium флори півострова використовували матеріали, зібрані впродовж 2011-2012 рр., а також відібрані в гербарії Інституту ботаніки імені М.Г. Холодного $(K W)$ та гербарії Нікітського ботанічного саду (YALT). Обсяг вибірки становив 4-6 сім'янок з 2-3 кошиків. Зразки плодів фіксували на латунному столику і напиляли тонким шаром золота у вакуумній камері, відтак досліджували з допомогою CEM JSM-6060 LA. В описах використовували загальноприйняту термінологію (Barthlott 1981; Сенников, Илларионова, 2001).

Плоди описували за таким планом:

- розміри та колір сім'янки;

- форма клітин екзокарпію;

- розташування антиклінальної стінки клітин екзокарпію щодо периклінальної стінки цих клітин;

- характер потовщення антиклінальної стінки;

- тип кутикули;

- наявність і кількість мікропапіл;

- рельєф поверхні плоду та периклінальної стінки;

- форма виростів клітин екзокарпію.

\section{Результати досліджень та їх обговорення}

Плід у досліджених представників роду Hieracium це коричнева до чорного, зрідка жовта циліндрична сім'янка з 10 ребрами. На іiі верхівці є папус, що складається з багатоклітинних щетинистих трихом із верхівками клітин, які виступають (Сенников, Илларионова, 2001). Носик на кінці плоду має підковоподібний потовщений валик (рис. 1, А). Клітини епідерми чотирикутні, прозенхімні (довжина більша від ширини у 4-5 разів).

Представники роду Hieracium характеризуються наявністю шипиків (конусоподібно-загострених шипоподібних виростів) на апікальному кінці клітини (рис. 1, Б). Вони розміщуються під гострим кутом до поверхні сім'янки і спрямовані в бік па- 
Досліджені зразки:

\begin{tabular}{|c|c|c|c|c|c|}
\hline Sect & Вид & Місцезростання & Колектор & Дата & Гербарій \\
\hline \multirow{3}{*}{ 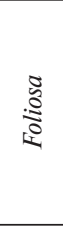 } & $\begin{array}{l}\text { Hieracium virosum } \\
\text { Pall. }\end{array}$ & $\begin{array}{l}\text { Пойма р. Сев. Донец. на меловом склоне. Луганская обл., } \\
\text { окрестности с. Станично - Луганское* }\end{array}$ & Конопля О.Н. & 22.07 .2002 & $K W$ \\
\hline & \multirow{2}{*}{$\begin{array}{l}\text { Hieracium } \\
\text { robustum } \text { Fr. }\end{array}$} & $\begin{array}{l}\text { Донецкая губерния, Луганский округ, окр. с. Кут, с. Троицкое. } \\
\text { Обнажение скалы пещанника }\end{array}$ & Лавренко Е. & 04.09 .1925 & $K W$ \\
\hline & & $\begin{array}{l}\text { Склон Долгоруковской яйлы, за с. Перевальное, на северо- } \\
\text { восток }\end{array}$ & Павленко-Баришева В. & 18.08 .2011 & $K W$ \\
\hline \multirow{2}{*}{$\frac{\sqrt{3}}{3}$} & $\begin{array}{c}\text { Hieracium } \\
\text { sabaudum L. }\end{array}$ & Лес над Ангарским перевалом & Павленко-Баришева В. & 20.07.2011 & $K W$ \\
\hline & $\begin{array}{c}\text { Hieracium } \\
\text { vasconicum Jord. } \\
\text { ex Martrin-Donos }\end{array}$ & Крым, урочище Таракташ & Павленко-Баришева В. & 21.07.2011 & $K W$ \\
\hline \multirow{2}{*}{ 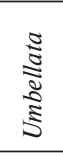 } & \multirow[t]{2}{*}{$\begin{array}{l}\text { Hieracium } \\
\text { umbellatum } \mathrm{L} .\end{array}$} & $\begin{array}{l}\text { Яйла Сев. Демерджи, центральная часть, раковошейково - } \\
\text { коротконожковая узколистноковыльная ассоциация между } \\
\text { скалистыми бартерами в седловине }\end{array}$ & Голубев Н.В. & 24.08 .1990 & $Y A L T$ \\
\hline & & Полтава, Триби, піски II тераси, вкриті молодим лісом & Зеров Д.К. & 03.09 .1923 & $K W$ \\
\hline$\frac{\sqrt{2}}{\sqrt[3]{2}}$ & $\begin{array}{l}\text { Hieracium } \\
\text { dshurdshurense } \\
\text { Üksip }\end{array}$ & Никитский хребет, Грушовая поляна, сосновый лес & Голубев Н.В. & 08.08 .1976 & $Y A L T$ \\
\hline \multirow{5}{*}{ 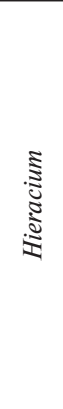 } & $\begin{array}{c}\text { Hieracium } \\
\text { levicaule Jord. }\end{array}$ & Алуштинский р-н, склоны г. Караби & Корженевский В.В. & 26.06 .1984 & $Y A L T$ \\
\hline & \multirow{2}{*}{$\begin{array}{l}\text { Hieracium } \\
\text { murorum L. }\end{array}$} & I лесной пояс, Долгоруковская яйла & Павленко-Барышева В. & 29.05 .2012 & $K W$ \\
\hline & & $\begin{array}{l}\text { Симферопольский район, Перевальное лесничество, верховья } \\
\text { р. М. Бурульча, буковый лес, на поляне }\end{array}$ & Дидух Я., Вакаренко Л. & 23.05 .1972 & $K W$ \\
\hline & $\begin{array}{l}\text { Hieracium } \\
\text { laevimarginatuim } \\
\text { Sennik. } \\
\end{array}$ & $\begin{array}{l}\text { АР Крым, Ялтинский район, ІІ лесной пояс, возле водопада } \\
\text { Учан-Су }\end{array}$ & Павленко-Барышева В. & 02.06 .2011 & $K W$ \\
\hline & $\begin{array}{l}\text { Hieracium } \\
\text { neglectipilosum } \\
\text { Sennik. }\end{array}$ & Крым, лес над Симеизом, III лесной пояс & Павленко-Барышева В. & 31.05 .2011 & $K W$ \\
\hline
\end{tabular}

П р и м і т к а: * Через поганий стан сім'янок кримського екземпляра (склон Долгоруковской яйлы, на северо-восток от с. Перевальное, 18.08.2011, Павленко-Барышева В.С.) ми вирішили дослідити плоди рослини, що ідентична до кримського зразка за макроморфологічними ознаками та умовами зростання. Тому в таблиці зазначено зразок із Луганської області.
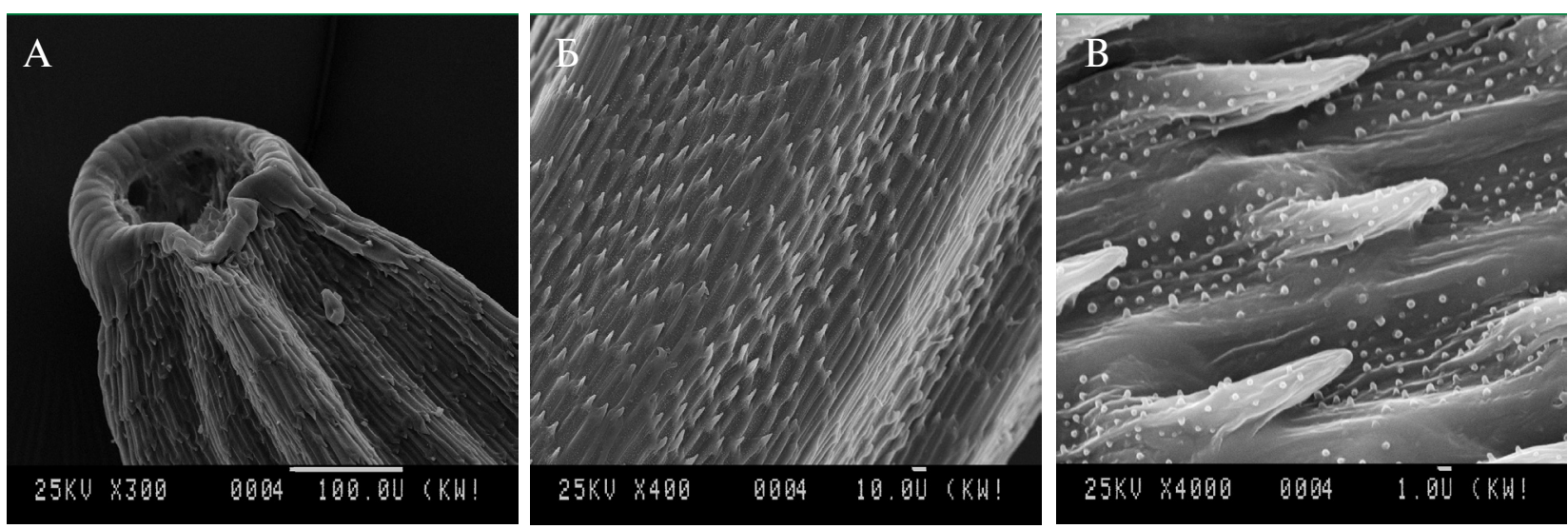

Рис. 1. Структурні особливості будови поверхні сім'янки представників роду Нieracium флори Криму: А - носик плоду (H. sabaudum); Б - первинний рельєф: шипоподібні вирости та ребра (H. тurorum); В - вторинний рельєф: зморшки та мікропапіли (H. murorum)

Fig. 1. Structural features of the achene surface of the genus Hieracium of the Crimean flora: A - spout of achene (H. sabaudum); $\mathrm{-}-$ primary sculpture: spikes and ribs (H. murorum); B - secondary sculpture: wrinkles and micro-papillae (H. murorum) 
пусу. Периклінальні стінки клітин екзокарпію відзначаються зморшкуватим рельєфом та наявністю мікропапіл (рис. 1, В). Слід зазначити, що кількість мікропапіл у досліджених видів різна, і залежить, на наш погляд, від ступеня зрілості плодів. У зрілих плодів їхня кількість більша порівняно з недозрілими.

\section{Sect. Foliosa}

Плід $\boldsymbol{H}$. virosum - коричнева до темно-коричневого сім'янка зі звуженою основою. Розміри плоду - 2,9-3,3 мм. Епідерма екзокарпію плоду в парадермальній площині сформована видовженими клітинами з шипиками із заокругленим кінцем (рис. 2, А). Антиклінальні стінки цих клітин потовщені. Периклінальні стінки клітин характеризуються зморшкуватим рельєфом та великою кількістю мікропапіл. У межах сім'янки спостерігаються два типи рельєфу. У міжреберних ділянках антиклінальні стінки містяться вище периклінальних, а по реберних ділянках, навпаки, периклінальні стінки виступають над антиклінальними. Таким чином, рельєф поверхні сім'янок, залежно від локалізації, різний: у реберній ділянці - горбкуватий, у міжреберній - ямчастий.

Плід $\boldsymbol{H}$. robustum - коричнева до темно-коричневого сім'янка зі звуженою основою. Розміри дещо більші, ніж у попереднього виду, - 3,23,6 мм. Екзокарпій плоду характеризується видовженими клітинами. Потовщення антиклінальних стінок не спостерігається. Периклінальні стінки мають зморшкуватий рельєф. Як і в попереднього виду, вирізняємо два типи рельєфу поверхні плоду: в міжреберній ділянці рельєф сітчастий, у реберній - горбкуватий (периклінальні стінки вище рівня антиклінальних). Шипики клітин екзокарпію мають гоструватий кінець (рис. 2, Б). Велика кількість мікропапіл на поверхні епідерми екзокарпію, проте трапляються поодинокі зразки і без мікропапіл.
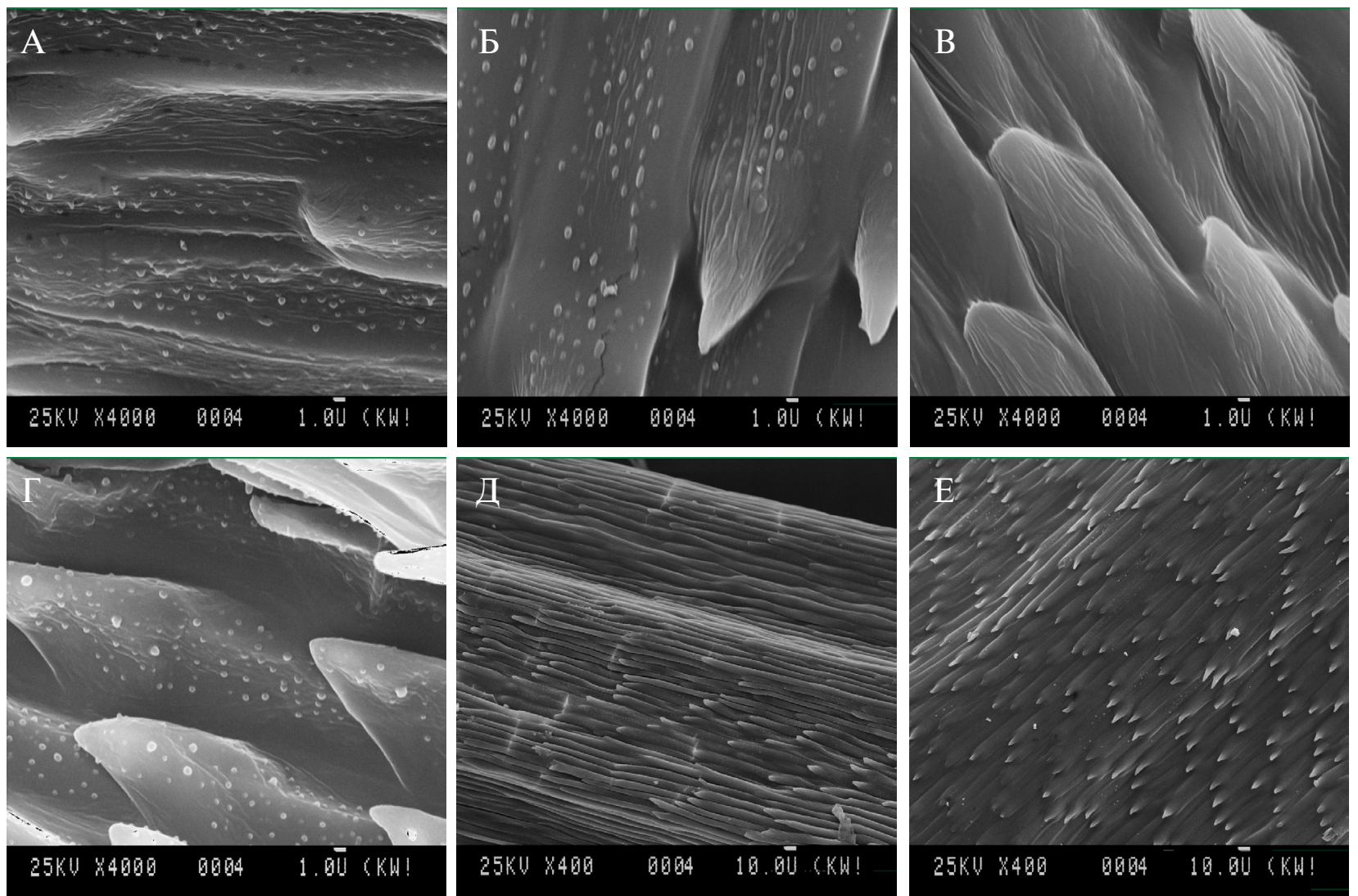

Рис. 2. Ультраструктура поверхні плоду Hieracium: А - H. virosum; Б - H. robustum; В - H. sabaudum; $\Gamma-H$. leavimarginatum; Д-H. umbellatum; $\mathrm{E}-H$. dshurdshurense

Fig. 2. Achene surface of Hieracium of the Crimean flora: A - H. virosum; Б - H. robustum; В — H. sabaudum; $\Gamma-H$. leavimarginatum; Д-H. umbellatum; $\mathrm{E}-\mathrm{H}$. dshurdshurense 
Отже, види $H$. virosum та $H$. robustum iз sect. Foliosa характерзуються видовженими клітинами екзокарпію (довжина перебільшує ширину в 6-9 разів). Рельєф плоду по реберних ділянках в обох видів горбкуватий. Мікропапіли розміщуються рівномірно по всій поверхні епідерми екзокарпію. Периклінальні стінки обох видів мають зморшкуватий рельєф. Види розрізняються за розташуванням периклінальних стінок щодо антиклінальних у міжреберних ділянках та за шипиками клітин екзокарпію. Так, у виду $H$. virosum у міжреберних ділянках антиклінальні стінки вище рівня периклінальних i, відповідно, рельєф ямчастий, шипики із заокругленим кінцем; у виду $H$. robustum у міжреберних ділянках антиклінальні стінки на одному рівні з периклінальними, отже, рельєф сітчастий, шипики із загостреним кінцем.

\section{Sect. Accipitrina}

Плід H. sabaudum - темно-коричнева до чорного сім'янка зі звуженою основою. Розміри більші, ніж у попередніх видів, - 3,5-4,0 мм. Епідерміс екзокарпію характеризується видовженими клітинами. Як і в попередніх видів, у межах сім'янки спостерігаються два типи рельєфу поверхні. По реберних ділянках периклінальні стінки клітин епідерми виступають над антиклінальними; в міжреберних ділянках - на одному рівні з периклінальними стінками. Рельєф, відповідно, по реберних ділянках - горбкуватий, у міжреберних - сітчастий. Інколи спостерігається потовщення антиклінальних стінок. Периклінальні стінки відзначаються зморшкуватим рельєфом. Шипики клітин екзокарпію мають заокруглений кінець. Мікропапіли на поверхні екзокарпію відсутні або є в невеликій кількості.

За зовнішнім виглядом та розмірами $(3,4-$ 4,0 мм) плоди $\boldsymbol{H}$. vasconicum подібні до плодів H. sabaudum. Потовщення антиклінальних стінок не спостерігається. Периклінальні стінки характеризуються слабозморшкуватим рельєфом. Рельєф плоду схожий із плодом попереднього виду. Шипики клітин екзокарпію, як і в попереднього виду, мають заокруглений кінець. Мікропапіли відсутні.

Досліджені види $H$. sabaudum та $H$. vasconicum (sect. Accipitrina) відзначаються прозенхімними клітинами епідерми екзокарпію (довжина більша від ширини в 5-6 разів). По реберних ділянках периклінальні стінки вище рівня антиклінальних і рельєф, відповідно, горбкуватий; у міжреберних ділянках периклінальні стінки на одному рівні з антиклінальними, рельєф - сітчастий. Види розрізняються за рельєфом периклінальних стінок клітин і наявністю мікропапіл. Так, H. sabaudum відзначається зморшкуватим рельєфом периклінальних стінок, мікропапіли бувають у невеликій кількості. Вид $H$. vasconicum характеризується слабозморшкуватим рельєфом периклінальних стінок клітин, мікропапіли відсутні.

\section{Sect. Umbellatum}

Плід H. umbellatum (рис. 2, Д) - коричнева до чорного сім'янка зі звуженою основою. Розміри менші, ніж у попередніх видів, - 2,4-3,3 мм. Епідерма екзокарпію плоду характеризується видовженими клітинами (довжина більша від ширини в 10-12 разів). Як і в представників попередніх секцій, наявні два типи рельєфу. По реберних ділянках периклінальні стінки виступають над антиклінальними - рельєф горбкуватий, у міжреберних ділянках антиклінальні стінки виступають над периклінальними - рельєф ямчастий. Зафіксоване потовщення антиклінальних стінок. Периклінальні стінки мають зморшкуватий рельєф. Шипики клітин екзокарпію із загостреним кінцем. Мікропапіли на поверхні епідерми екзокарпію містяться в міжреберних ділянках плоду в невеликій кількості.

За зовнішнім виглядом та розмірами плоди виду H. levicaule також подібні до плодів $\boldsymbol{H}$. murorum. На відміну від попередніх видів цієї секції, рельєф у міжреберних ділянках та по ребрах не відрізняється. На обох ділянках периклінальні стінки клітин екзокарпію містяться над антиклінальними. Рельєф поверхні горбкуватий. Потовщення антиклінальних стінок не спостерігається. Рельєф периклінальних стінок, шипики та мікропапіли подібні до таких у $\boldsymbol{H}$. laevimarginatum.

Отже, види sect. Hieracium характеризуються видовженими клітинами екзокарпію, зморшкуватим рельєфом периклінальних стінок клітин, загостреними кінцями шилоподібних виростів і наявністю мікропапіл. Проте в усіх видів цієї секції довжина клітин перевищує ширину лише в 3-4 рази, що може бути додатковою діагностичною ознакою у визначенні sect. Hieracium. Діагностичними на рівні видів можуть бути такі ознаки: ширина основи шипоподібних виростів, розташування периклінальних стінок щодо антиклінальних у міжреберних ділянках і наявність потовщення антикліналь- 
них стінок. Так, у H. murorum рельєф поверхні у міжреберних ділянках ямчастий, гачок клітин епідерми екзокарпію при основі вужчий за саму клітину; у видів $H$. laevimarginatum та $H$. neglectipilosum рельєф поверхні в міжреберній ділянці сітчастий, шипик при основі за шириною дорівнює клітині епідерми екзокарпію, у H. levicaule рельєф міжреберних ділянок - горбкуватий, шипики подібні до таких у H. laevimarginatum.

Отже, в результаті порівняльного аналізу ультраструктури поверхні плодів Hieracium флори Криму виявлено, що види досліджуваних секцій характеризуються горбкуватим рельєфом плоду по реберних ділянках, шипиками в клітинах екзокарпію, зморшкуватим рельєфом поверхні клітин екзокарпію та наявністю мікропапіл.

Додатковими діагностичними ознаками на рівні секції є: відношення довжини клітин епідерми екзокарпію до їхньої ширини, форма виростів клітин епідерми екзокарпію, наявність і локалізація мікропапіл, рельєф поверхні плоду в міжреберних ділянках. Ми підтверджуємо дані О.М. Сеннікова та І.Д. Ілларіонової (Сенников, Илларионова, 2001) стосовно морфології плодів видів H. umbellatum i H. virosum та доповнюємо їх відомостями щодо мікроморфології сім'янок цих видів.

\section{Висновки}

Отже, вперше описано ультраструктуру поверхні епідерми плодів 10 видів роду Hieracium флори Криму. Зокрема, встановлено спільні (горбкуватий рельєф плоду по реберних ділянках, шипики на апікальних кінцях клітин епідерми екзокарпію, зморшкуватий рельєф поверхні клітин епідерми екзокарпію, наявність мікропапіл) і відмінні (відношення довжини клітин епідерми екзокарпію до їхньої ширини, локалізація мікропапіл, форма кінця шипика, розташування антиклінальних стінок клітин екзокарпію стосовно периклінальних у міжреберних ділянках) ознаки ультраструктури поверхні плоду. Виявлені додаткові діагностичні ознаки: на рівні секцій (відношення довжини клітин епідерми екзокарпію до їхньої ширини, локалізація мікропапіл); на рівні виду (розташування антиклінальних стінок клітин епідерми екзокарпію щодо периклінальних у міжреберних ділянках, форма кінця шипику (sect. Foliosa), його ширина при основі (sect. Hieracium), наявність або відсутність мікропапіл (sect. Accipitrina).
Автор висловлює подяку науковому співробітникові Інституту ботаніки імені М.Г. Холодного С.М. Жигаловій, старшому науковому співробітникові цієї установи З.М. Цимбалюк та старшому науковому співробітникові Ботанічного саду імені О.В. Фоміна О.А. Футорній за допомогу в підготовиі статті до друку та цінні поради.

\section{СПИСОК ЛІТЕРАТУРИ}

Ена А.В. Природная флора Крымского полуострова. Симферополь: Н. Оріанда, 2012. - 231 с.

Ольшанський I.Г. Морфологічна будова та ультраструктура поверхні насінин видів родини Juncaceae Juss. флори України // Укр. ботан. журн. - 2009. - 66, № 2. C. $179-189$.

Перегрим О.М., Вакуленко Т.Б. Анатомічна будова та ультраструктура поверхні насінин видів роду Euphrasia L. (Orobanchaceae) флори України // Укр. ботан. журн. 2009. - 66, № 1. - С. 111-117.

Сенников А.Н., Илларионова И.Д. Морфологическое и анатомическое строение семянок видов рода Hieracium (Asteraceae) и близких родов // Ботан. журн. - 2001. 86, № 3. - С. 37-59.

Черепанов С.К. Свод дополнений и изменений к «Флоре СССР». (тт. 1-30). - Л.: Наука, 1973. - 668 с.

Шляков Р. Н. Ястребинка - Hieracium L., Ястребиночка Pilosella Hill // Фл. европ. части СССР. - Л.: Наука, 1989. - T. 8. - C. $140-379$.

Barthlott W. Epidermal and seed surface characters of plants: systematic applicability and some evolutionary aspects // Nord. J. Bot. - 1981. - 1(3). - P. 345-354.

Bednorz L., Podsiedlik M. A study on achene macro- and micromorphological characters of Polish species of the Senecio jacobaea group // Acta Agrobot. - 2013. - 66(2). P. 13-20.

Euro+Med Plant Base. Режим доступу до сайта: http://www. emplantbase.org/home.html. Accessed 2013.

Johnson L.A., Huish K.H., Portery J.M. Seed surface sculpturing and its systematic significance in Gilia (Polemoniaceae) and segregate genera // Int. J. Plant Sci. - 2004. - 165(1). P. $153-172$.

Schneider A. A., Boldrini I.I. Microsculpture of cypselae surface of Baccharis sect. Caulopterae (Asteraceae) from Brazil // Anales Jard. Bot. Madrid. - 2011. - 68(1). - P. 107- 116.

Shekhar S., Pandey A.K., Anderberg A.A. Cypsela morphology and anatomy in some genera formerly placed in Inula (Asteraceae: Inuleae - Inulinae) // Rheedea. - 2011. 21(1). - P. 13-22.

Sulaiman I.M. Scanning electron microscopic studied seed coat patterns of five endangered Himalayan species of Meconopsis (Papaveraceae) // Ann. Bot. - 1995. - 76. - P. 323-326.

Рекомендує до друку

Є.Л. Кордюм
Надійшла 25.04.2014 p. 


\section{В.С. Павленко-Барышева}

Институт ботаники имени Н.Г. Холодного НАН Украины, г. Киев

\section{УЛЬТРАСТРУКТУРА ПОВЕРХНОСТИ ПЛОДОВ ВИДОВ РОДА НIЕRACIUM ФЛОРЫ КРЫМА}

Впервые с помощью сканирующего электронного микроскопа исследована ультраструктура поверхности семянок 10 видов рода Hieracium флоры Крыма. Установлены общие (холмистый рельеф, крюки на апикальных концах клеток эпидермы экзокарпия, складчатый рельеф поверхности клеток экзокарпия, наличие микропаппил) и специфические признаки ультраструктуры плода исследованных видов. Большинство из них являются дополнительными диагностическими признаками на уровнях секции (отношение длины клеток экзокарпия к их ширине, локализация микропаппил) и вида (форма кончика шипика в sect. Foliosa; наличие микропаппил у представителей sect. Accipitrina, ширина основы клюка (sect. Hieracium), рельєф поверхности плода в межреберном участке).

Ключ г в ы е слов в : Hieracium, семянка, ультраструктура поверхности, СЭМ, флора, Крым.

\section{V.S. Pavlenko-Barysheva}

M.G. Kholodny Institute of Botany, National Academy of Sciences of Ukraine, Kyiv

\section{ULTRASTRUCTURE OF THE ACHENES SURFACE IN SPECIES OF THE GENUS HIERACIUM IN THE CRIMEAN FLORA}

For the first time, the fruit surface ultrastructure for 10 species of the genus Hieracium in the Crimean flora was studied using SEM. Both common (tumulose surface on the costal region; hooks on the apical ends of exocarp cells, wrinkled surface of the cells; globular structures - micropapillae) and specific characteristics of the achenes ultrastructure of the studied species have been revealed. Most of them are additional diagnostic characters at the section level (ratio of length to width of the exocarp cells, localization of micropapillae) and at the species level (shape of the hook ends in sect. Foliosa; presence of micropapillae in sect. Accipitrina; basal width of hooks in sect. Hieracium; type of surface in the intercostal region).

Ke y words: Hieracium, achene, SEM, surface ultrastructure, flora, Crimea. 